\title{
A briga dos Néris
}

EVALDO CABRAL DE MELLO

A concatedral da Madre de Deus ergue-se na extremidade meridional do istmo onde nasceu o Recife. Desde sua edificaçáo, em fins do século XVII, até o período regencial, que nacionalizou os bens do clero, o templo pertenceu à Congregação do Oratório, fundada por Sáo Felipe Néri, na Itália, ao tempo da reforma católica, e dali transplantada a França, Espanha e Portugal. Nenhuma comunidade religiosa esteve táo identificada à fortuna da cidade, nem mesmo os

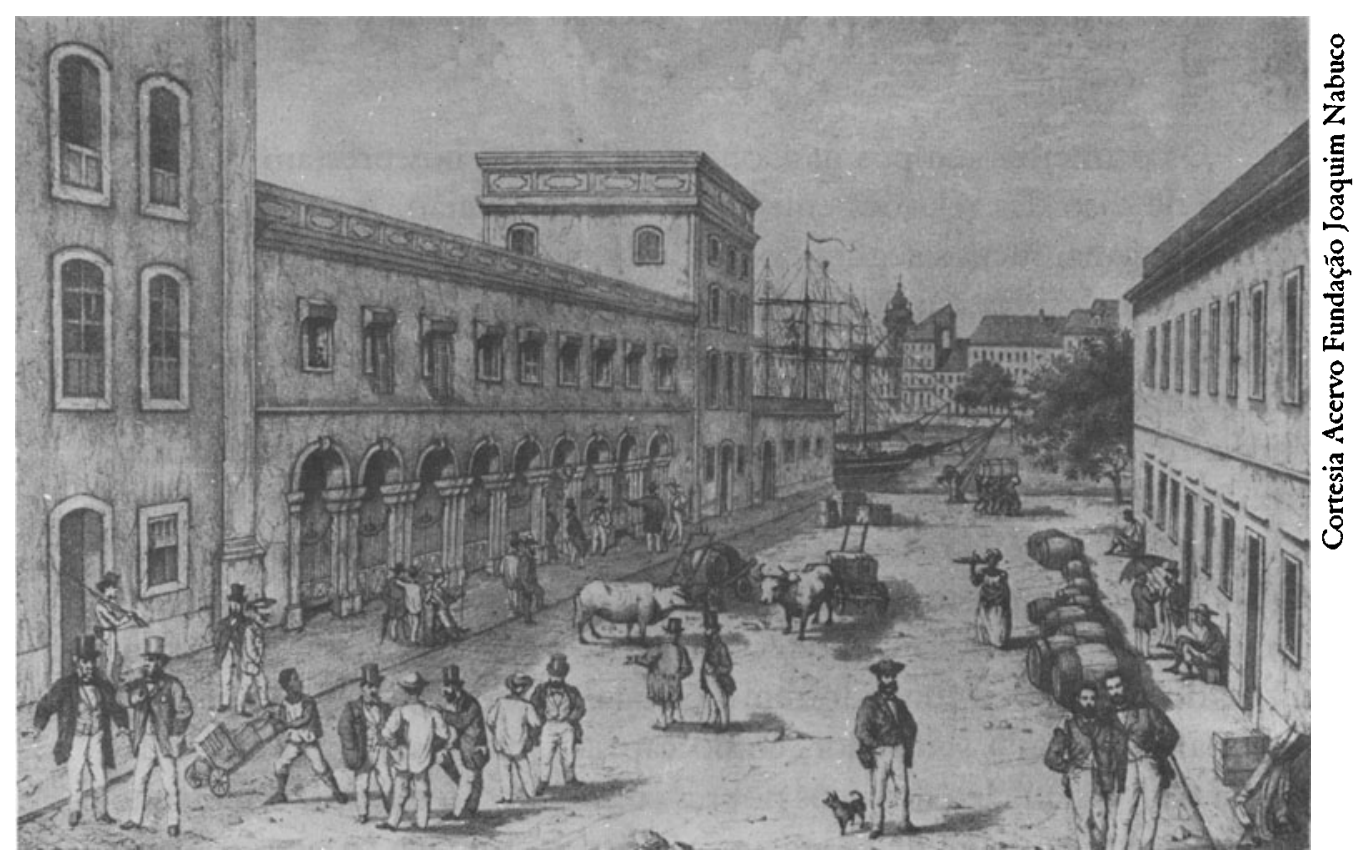

Largo da Alfandega, Convento e lateral da Igreja da Madre de Deus

carmelitas turôes, que lhe deram Nossa Senhora do Carmo como padroeira. A açáo dos néris, também designados na terra por lóios (termo reservado na metrópole aos religiosos da ordem de Sáo João Evangelista), por recoletos (vale dizer, reformados), ou ainda por manigrepos (ermitóes do Pegu), seria decisiva para a conquista da autonomia municipal e se tornou táo marcante na vida colonial que um governador do século XVIII, Henrique Luís Pereira Freire, acusará os padres de quere- 
rem "governar esta capitania tanto no militar como no público e eclesiástico", a ponto de se intrometerem "em matérias que lhes não tocam". Às vésperas da Independência e do Império, o qual, dentro em breve, extinguirá a casa, o autor anônimo das Revoluçóes do Brasil, insuspeito de simpatias nativistas, aludirá aos "anfíbios congregados do Oratório, que náo sáo frades nem clérigos, mas são tudo no seu convento do Recife", de vez que possuíam, segundo a voz do povo, "cinco grandes virtudes: $1^{\mathrm{a}}$ servirem de empenho para tudo; $2^{\mathrm{a}}$ assistirem aos moribundos; $3^{\text {a }}$ darem esplêndidos banquetes; $4^{\mathrm{a}}$ pagarem as suas dívidas; $5^{\mathrm{a}}$ emprestarem dinheiro aos seus amigos", num contraste que lhes era favorável em meio à decadência moral e material do clero, com carmelitas, beneditinos e franciscanos, cujos conventos eram reputados "coutos ou baluartes em que se acastelavam a ignorância, o atrevimento e a libertinagem de costumes". Há muito o Oratório transformara-se numa instituiçăo eminentemente recifense, reversáo completa do seu impulso original.

Os primeiros tempos da Congregaçáo entre nós prestam-se a um estudo de caso das relações entre nativismo e religião. A sorte da filial pernambucana, menos segura do que a de seus concorrentes, ordens há muito estabelecidas em Portugal ou na capitania, achou-se seriamente ameaçada por um conflito interno que correspondeu, no plano eclesiástico, a uma espécie de pré-guerra dos mascates por néris interpostos. A vitória final dos religiosos da Madre de Deus, apoiados pela mascataria em detrimento dos irmáos de Santo Amaro, sustentados por Olinda, traduzir-se-á na sólida aliança de interesses que abrirá o caminho à conquista da ảutonomia municipal do Recife. À consecuçáo deste objetivo, não foi alheia a vocação de poder dos néris, a qual lhes viera, por assim dizer, do berço. Seu fundador em Portugal, o açoriano Bartolomeu do Quental, formara a seu redor, como capeláo, confessor e pregador da capela real, um núcleo de laicos nobres cuja educaçáo religiosa submeteu a uma disciplina diária de exercícios espirituais, baseada na oraçáo mental e quase táo rigorosa como a que impôs aos próprios clérigos que serviam no paço, atividades que náo o impediriam por outro lado, de desenvolver uma vigorosa missão pastoral por toda a arquidiocese de Lisboa.

Num modesto esboço do que será o Oratório português, o padre Quental criou (1659) uma congregação de sacerdotes, sob a invocaçáo de Nossa Senhora das Saudades e sob o patrocínio da Rainha Regente, cuja proteção os néris náo se cansaráo de recordar aos filhos e netos de D. Luísa de Gusmão que se sentarão no trono. Quando a crise entre D. Afonso VI e o infante D. Pedro saldou-se pela deposição do monarca 
em benefício do irmão, o padre Quental encontrava-se do lado certo da barricada. No ano seguinte (1668), fundava-se a Congregação dos Clérigos do Oratório de Nossa Senhora da Assunçáo. D. Pedro II, cujo reinado será decisivo para a consolidação da entidade em Portugal e no Brasil, demonstrar-lhe-á o interesse e o carinho particulares de quem certamente era reconhecido ao padre Quental pelos serviços prestados junto à nobreza quando da sua ascensáo à regência.

O interesse de Quental pelo Brasil predatou o estabelecimento da Congregação em Portugal. Poderia mesmo tê-lo abortado. Informado da situação lamentável em que o domínio e a guerra holandeses haviam colocado a igreja pernambucana, ele cogitara uns tempos em dedicar-se ao trabalho missionário na antiga capitania duartina. Dissuadiram-no a inspiração divina e os conselhos dos amigos, representando-lhe que "a sua América era Lisboa". Em seu lugar, enviou o padre João Duarte do Sacramento, pertencente também aos quadros da capela real e que fundará o Oratório de Pernambuco. Uma precoce vocaçáo religiosa, estimulada por um tio frade que o treinara nas técnicas espirituais de frei Luís de Granada, fizera-o, menino ainda, credenciário ou coroinha do altar-mor. D. João VI e a mulher notaram o zelo e fervor com que o rapazinho se desincumbia, lendo neles os sinais de algum dote sobrenatural; daí que o convocassem quando algum dos infantes enfermava, para que segurasse a real criança nos braços, alimentada muitas vezes com as aparas das hóstias que Sacramento cortara. As práticas do padre Quental vieram avivar-lhe a devoção; e tendo recebido ordens menores, imaginou tornar-se capucho. Uma voz interior sussurrou-lhe, contudo, um diferente caminho de salvação. Falecido D. Joáo IV (1656), quis trilhá-lo e, como se tivesse metido num navio para a Índia, dele foi retirado a força por ordem expressa da Rainha Regente, a qual mandou vigiá-lo de perto todas as vezes que, na ribeira de Lisboa, aprestava-se nau para Goa. O padre Quental logrou convencê-la finalmente a deixálo partir para Pernambuco na companhia do padre João Rodrigues Vitória, seu companheiro de ordenação.

A atividade missionária, encarnada na conversáo do gentio, constituiu o propósito principal do Oratório de Pernambuco, temeroso de que frutificasse a heresia que os holandeses haviam semeado na terra. Assim indica a escolha (1662), pelos padres Sacramento e Vitória, da ermida de Santo Amaro. Narra um cronista setecentista da Madre de Deus que, decorridos os primeiros anos entre os índios do Sáo Francisco, foi-lhes necessário dispôr de hospício para se acolherem nas viagens periódicas ao Recife, aonde vinham suprir-se de vinho, hóstias e de outros artigos indispensáveis. As autoridades eclesiásticas deram-lhes 
para escolher, entre as igrejas abandonadas de Olinda, a que melhor lhes conviesse, oferecimento que rejeitaram por "amor do retiro", optando pela capela perdida nos mangues de Água Fria e edificada no começo do século, "táo pequena que do chão se chegava às telhas com as mãos". Conhecendo a valia dos religiosos na Corte ou sinceramente impressionado pelo seu ardor apostólico, o governador Brito Freyre mandou construir do seu bolso e pegado à igrejinha, que fez reformar, um "corredorzinho com uns cubículos muito estreitos e pequeninos" que servissem de recolhimento aos padres quando de regresso do sertão. Desconhece-se o texto dos estatutos redigidos pelo padre Sacramento para a casa de Santo Amaro. Uma notícia da sua vida descreve-os como extremamente rigorosos, no tocante às regras de comportamento a serem obedecidas no exterior, como na vertente interna, do quotidiano da comunidade, prescrevendo um "modo de vida eremítica", para usar as palavras de uma representação de 1700 . Nela, os religiosos deviam observar um silêncio de Trapa; andar descalços; jejuar o ano inteiro e passar a pão e água três vezes por semana; orar nas sextas-feiras durante as horas da Crucificaçáo; rezar as horas canônicas no coro $\mathbf{e}$ as matinas à meia-noite; $\mathrm{e}$ habitar em celas providas apenas de esteira, cobertor, banco e de uma tábua na parede a modo de escrivaninha. Sustentando-se exclusivamente do pecúlio com que haviam ingressado na instituição, estavam proibidos de se engajarem em qualquer operaçáo comercial, de receberem óbolos pelas missas, de pedirem esmolas, de se servirem de criados. Do serviço doméstico, eles mesmos se encarregavam, segundo um rodízio de que não se isentava sequer o seu prior ou prepósito. A congregação agora fundada, a Rainha Regente tomou sob sua proteção. Definia-se assim a fisionomia original do Oratório de Pernambuco: trabalho missionário e estilo de vida ascético.

Durante nove anos, o recolhimento de Santo Amaro regeu-se pela disciplina do padre Sacramento, provisoriamente aprovada pelo cabido de Salvador. Somente em 1671, tratou-se de enviar a Roma o padre Vitória para obter a confirmação da Santa Sé, demora que se prendeu à falta dos recursos necessários a táo dispendiosa viagem. Na sua passagem por Lisboa, o padre Quental confiará ao emissário o encargo de conseguir $o$ assentimento do Vaticano às constituiçóes que redigira, por sua vez, para a recoleta de Lisboa. A tarefa não será das mais fáceis, devido à intransigência do criador do Oratório português, que, aliás, já levara de vencida a oposição dos cônegos lisboetas. Suas regras divergiam em pontos fundamentais dos estatutos da congregação italiana, elaborados depois da morte de Sáo Felipe Néri; e Quental não abria mão daqueles pontos que julgava indispensáveis ao funcionamento da entidade portuguesa. Num primeiro momento, os esforços do padre 
Vitória fracassaram. Inicialmente (1671), o Papa aprovou a criação do Oratório de Lisboa, dando-lhe as constituiçóes chamadas de Vallicella, do nome da principal casa dos néris italianos, fazendo concessão idêntica à recoleta de Pernambuco. À Cúria, náo agradavam novidades em matéria de disciplina e de organizaçáo, temor histórico de que a Igreja se imbuíra face aos riscos de heresia doutrinal e de autonomia eclesial. No caso do recolhimento de Santo Amaro, pensara o Vaticano que os estatutos do padre Sacramento "pecavam por excesso de rigor, por não ser possível às forças humanas aturar-se tanta austeridaden. Mas, enquanto em Pernambuco aceitara-se a decisáo pontifícia, no Reino o padre Quental, sob a aparência de anuir, continuava a bater-se por uma adaptação, invocando as exceçóes que a Santa Sé já abrira para outras casas, como a de Madrid. Neste propósito, Quental levara a reboque o padre Sacramento. Para o fundador da Congregaçáo lusitana, a flexibilidade e o liberalismo disciplinares do regime de Vallicella desfechariam um golpe mortal no seu instituto. Queixava-se um alto funcionário da Cúria que, ao pleitear restriçōes importantes à regra de São Felipe Néri, Quental desejaria "chuva no nabal e sol na eira", para usar a expressáo vernacular da vontade de tirar vantagem em tudo. Na realidade, a Quental tanto se lhe dava de São Felipe Néri quanto de qualquer outra norma, contanto que a sua congregação dispusesse segundo seus termos, da confirmação papal. Graças principalmente às gestóes do Embaixador de Portugal è intercessão de personalidades romanas, a quem o recomendaram o Regente e sua irmá, D. Catarina de Bragança, rainha viúva da Inglaterra, o padre Vitória logrou por fim alcançar o desiderato quentaliano. Um breve de 1672 aprovou as constituiçóes lisboetas para a casa do Reino e para a de Pernambuco.

Os estatutos de Lisboa eram muito mais que uma mera adaptaçăo de Vallicella, pois incorporavam uma série de regras cuja severidade tornava-as inteiramente alheias à inspiração eclética e meio boêmia de Sáo Felipe Néri. Este, por exemplo, previra a prática diária da oração mental, deixando-a, porém à discrição individual. $O$ padre Quental fixou-lhe tempo e hora, adicionando-lhe a obrigaçáo de ser feita na companhia da comunidade. Ademais criou deveres que não recolhera o italiano, como o exame de consciência, o jejum todas as festas e sábados, os exercícios espirituais de nove dias por ano, a proibiçáo de pregar fora da Congregação, bem como a exigência de só se sair à rua na companhia de outro oratoriano e sempre a pé (nunca a cavalo, liteira ou coche), a de năo assistir a festividades profanas, nem de se alimentar ou pernoitar fora do recolhimento, sequer na casa paterna. Concessão importante à sociedade portuguesa de seiscentos, Quental adotou também o requisito de limpeza de sangue, que excluía os descendentes de cristăo novos, 
mouros e índios. Escusado assinalar que o sistema italiano tampouco previra a cura de almas, as missóes pedestres no Reino ou as missóes de gentilidade no Brasil, consagradas pelas constituiçóes portuguesas. Neste caso, as espórtulas das missas revertiam ao patrimônio da Congregaçáo, o que náo acontecia no regime de Vallicella, o qual permitia sua apropriação pelos religiosos.

Datam da adoçáo dos estatutos de Lisboa os primeiros desentendimentos entre os néris pernambucanos. O padre Sacramento os favorecia, mas a pequena comunidade de Santo Amaro rejeitou-os por maioria de votos, preferindo reger-se pelos de Vallicella e diligenciando em Roma a anulação, no que lhe tocava, do breve de 1672. Para celebrar a escolha, organizaram-se três dias de festa em louvor do Espírito Santo. Apesar da ascendência que exercia entre os irmãos, Sacramento optou pela tática de dobrar as resistências de forma mansa e sinuosa. O fato é que, pouco tempo depois, já se regiam por uma miscelânea de regras, composta à base das constituiçóes portuguesas e das de Vallicella, texto que, além de ilegal, era observado pro viribus, isto é, de acordo com a vontade de cada um. A transação não estava necessariamente condenada ao malogro, tendo-se em vista a modéstia de meios da casa pernambucana, reduzida naquela altura ao pequeno núcleo de Santo Amaro e aos padres dispersos pelas aldeias, mas durou pouco, pois logo se passava a ler no refeitório a regra do padre Quental, sinal de que seus partidários haviam ganhado terreno.

A iniciativa de instalar-se no Recife traria à discórdia sua dimensão secular. Ela inspirava-se no precedente dos carmelitas de Olinda, que haviam logrado a aprovaçáo régia para o estabelecimento de um hospício na praça. Em ambos os casos, o processo foi o mesmo: numa primeira etapa, edificou-se o recolhimento, com uma pequena igreja, destinada ao uso exclusivo dos religiosos e destituída, portanto, de porta para a rua; posteriormente, apresentou-se o fato consumado, arrancando-se à Coroa, renitente na oposiçáo a novos conventos, a licença para o acesso da populaçáo. Nestas medidas iniciais, os recoletos de Santo Amaro contaram com o apoio do bispo, D. Estevão Brioso de Figueiredo, e do governador Aires de Souza de Castro (1678-1682), de maneira a superar os obstáculos levantados pela Câmara de Olinda, escarmentada pela sua experiência com os carmelitas. Era o começo da dissensão entre a nobreza da terra e o Oratório. Com razáo, a Câmara enxergava na manobra o prelúdio da mudança definitiva para o Recife, traiģão que os néris viriam tramando há algum tempo. Donde a sua resistência a qualquer pretensão dos padres, inclusive ao aumento da quota de vinho isenta do pagamento do imposto. Contudo, os verea- 
dores acabaram cedendo, com o que o padre Sacramento passou à segunda fase da operação, implorando ao Regente a tomar o Oratório sob sua proteção, autorizando a porta aberta e o ingresso dos fiéis. Concluída a edificação da igreja e do recolhimento, foi a vez de solicitar-se a transferência de Santo Amaro ("retiro mui distante", próprio só a um noviciado), para o Recife, de onde se poderia dar redobrado impulso à evangelizaçáo dos tapuias, a que eram os únicos a se atreverem, devido à ferocidade daquele gentio e às paragens escabrosas que habitavam. Para tanto, reivindicavam a ordinária de quinhentas arrobas de açúcar pagas aos jesuítas desde o reinado de $\mathrm{D}$. Sebastião. Na Corte, surgiram dificuldades que Sacramento soube aplainar, valendo-se da influência da casa de Lisboa, através das religiosas de Xabregas, onde o ministro conde de Vila Maior e futuro marquês de Alegrete, tinha filha e irmâs. Em 1681, a Coroa confirmou a casa do Recife. Estava fundada a Madre de Deus.

Padre Sacramento escondera o jogo, pois a instalaçāo no Recife nada tinha a ver com as necessidades do labor missionário. Ela visava, ao contrário, desbravar o campo de atividade que, em Portugal, constituía a preocupaçáo maior de Bartolomeu de Quental, a pastoral em áreas de alta densidade demográfica. O manifesto dos dissidentes confessará o motivo real ao aludir ao "pouco fruto que se fazia nas almas no lugar de Santo Amaro, entre matos, distante da povoação quase uma légua". Em meados do século XVIII, o cronista da Madre de Deus alterará a sucessão cronológica, apresentando a mudança como decorrente da adoção dos estatutos de Lisboa quando a sequiência temporal foi precisamente a inversa, mistificação ou equívoco em que incorrerá também o autor de uma vida do padre Sacramento. A iniciativa correspondia assim à intençáo deliberada de assegurar o crescimento do Oratório de Pernambuco mediante sua inserçáo no meio urbano, tanto mais que o tipo de religiosidade oratoriana parecia particularmente adequada às camadas médias e superiores de uma comunidade citadina. Esta era, aliás, a estratégia já seguida no Reino, onde os congregados estabeleciam-se sempre nas cidades: e a exceção confirma a regra, pois a primitiva vocação eremítica de alguns dos seus fundadores foi em breve abandonada em favor da implantaçáo em Freixo de-Espada-à-Cinta (Trás-os-Montes) como em Goa. e em Pernambuco. Ao associar seu destino à expansão do Recife, os néris de Santo Amaro apostavam no êxito da nova classe de comerciantes reinóis que ali prosperava, como indica a atitude da Câmara de Olinda, antes assinalada, e sobretudo o apoio dispensado aos padres por um mascate da projeção e da fortuna de Antônio Fernandes de Matos, que, já o veremos, encabeçou um verdadeiro programa de promoçáo do Recife, no qual se confundiam as 
aspiraçóes de enriquecimento individual, de desenvolvimento urbano e de poder municipal. Foi Fernandes de Matos quem doou o terreno para a construção do recolhimento, rematando uma bem-sucedida operação imobiliária (a que a Câmara também criara entraves), pela qual obtivera a propriedade de uma extensa área que, arrancada à maré, aterrara $\mathrm{e}$ arruara na ponta sul da povoaçáo. Suas relaçóes com os néris, ele as herdara do sogro, o médico Domingos Monteiro de Oliveira, que os ajudara para a edificação da casa de Santo Amaro, em cuja igreja viria a sepultar-se. Quanto a Fernandes de Matos, pode-se dizer que, por devoção de católico e por astúcia de mascate, tornou-se o grande benfeitor da Madre de Deus. Aliás, a doação por ele feita aos néris, dado significativo, só se consumou em 1687 , delonga que imputava não só ao inventário da mulher como à atitude de "alguns prelados do dito convento", alusão crítica às reservas que os entáo dissidentes de Santo Amaro contrapunham ao projeto de ampliaçáo do hospício do Recife.

O primitivo convento, obra modesta de taipa, estava apto, contudo, a alojar doze padres, número indicativo da energia com que os oratorianos encaravam o cultivo da sua vinha recifense. A igreja anexa contava com a capela-mor e dois altares laterais, sendo "forrada de esteira", na descriçăo do cronista, "porém toda pintadinha e devota". $O$ inconveniente inicial, de náo dispor de porta aberta para a rua, pôde ser contornado antes ainda da autorização régia, graças à manha dos néris, muitas vezes tấo jesuíticos quanto seus concorrentes inacianos, cuja ascendência religiosa e pedagógica no Reino viriam a assumir no século XVIII. De modo a não privar os leigos dos regalos espirituais que thes propiciavam os filhos de São Felipe Néri, permitiu-se-lhes acesso ao templo através da portaria do recolhimento. A localizaçáo da Madre de Deus náo poderia ter sido mais feliz em termos da projetada conquista do Recife. Ao invés dos conventos já existentes na povoação, como ode São Francisco, que datava do começo do século, o colégio da Companhia de Jesus ou o da Penha, implantados depois da restauração, ou o dos carmelitas, que se haviam por pouco antecipado aos recoletos, estes se foram alojar no coraçáo da antiga urbe nassoviana, em plena freguesia de São Frei Pedro Gonçalves, desservida apenas pela matriz do Corpo Santo, ao passo que seus concorrentes, segundo a tradição monacal da instalaçáo fora-de-portas, nas periferias urbanas, viviam do outro lado do rio, na banda de Santo Antonio. Vantagem considerável a da Madre de Deus, em se tratando de contender mormente com os discípulos de Santo Inácio, eles também, como os néris, movidos por uma visão ativa e prática da vida religiosa.

Pouco tempo antes de seu falecimento (1686), o padre Sacra- 
mento escreveu, por duas vezes, ao padre Quental, solicitando o envio de um congregado para supervisionar a aplicação das regras lisboetas, não recebendo resposta. $O$ fundador relutava em consequiência das dificuldades por que passava no Reino o instituto mas sobretudo temeroso de que a preferência anteriormente manifestada em Santo Amaro pela disciplina de Vallicella conseguisse novamente sobrepor-se aos desígnios do seu prepósito. O fato é que o padre Sacramento viria a falecer com o desgosto de deixar em suspenso um assunto que tanto tinha a peito. Dezembro de 1685 , a febre amarela atacou pela primeira vez Pernambuco e, mais intensamente, o Recife. Com malícia eclesiástica, o compilador da sua hagiografia refere que "os sacerdotes que havia na terra todos fugiram para fora", faltando à sua obrigação primeira de ministrar

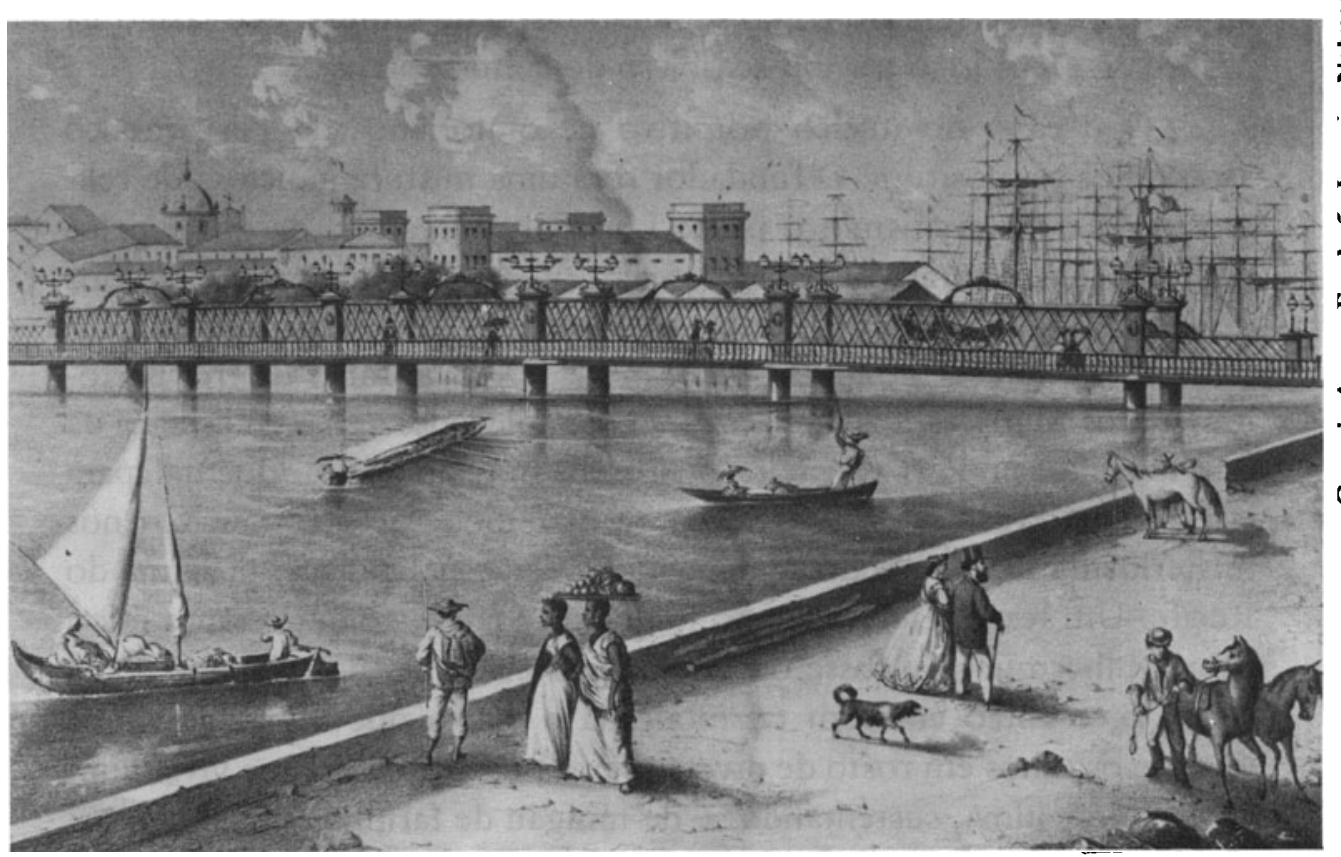

Vista da Ponte Nova do Recife e, ao fundo, Igreja da Madre de Deus e Convento

as necessidades religiosas dos enfermos e moribundos; ou, entăo, adoeceram também, como aconteceu ao vigário. Destarte a responsabilidade de socorrer a povoaçáo recaiu exclusivamente sobre os oratorianos, os quais iam de porta em porta, noite e dia, administrar os santos óleos, ajudados apenas pelos moleques de rua, que portavam as varas do pálio e as lanternas, como se fossem pessoas de condição. Coube-lhes também o trabalho penoso de enterrar os mortos, muitos deles abandonados pelo medo, na portaria da Madre de Deus para que se lhes desse sepultura cristã. A todas estas obrigaçóes entregava-se o padre Sacramento, 
sem dar atenção às filiais admoestaçōes que lhe faziam as autoridades e pessoas gradas, para que se retirasse para Santo Amaro. O pouco tempo que se permitia de repouso passava-o a orar e a chorar diante do Santíssimo Sacramento. Pregando no domingo de advento, previu a própria morte $e$ a de quase todos os presentes. A epidemia recrudesceu e a praça achou-se ameaçada também pela fome, no isolamento do cordáo sanitário que the impuseram as freguesias rurais, ao sustarem o suprimento de víveres. Neste primeiro surto do mal, pereceram "quase todos os padres desta Congregaçáo", afirma o seu hagiógrafo, "e foram os mais doutos e antigos dela" . Padre Sacramento morreu nos primeiros dias de janeiro, em meio aos sinais sobrenaturais que já marcavam seu passamento, inclusive a coincidência de ancorar no Recife, no momento em que se rezava o ofício de corpo presente pela sua alma, o navio que trazia a bula para sua sagraçáo como segundo bispo de Olinda. Seu jazigo na Madre de Deus logo tornou-se objeto do culto recifense.

O decano do núcleo primitivo de oratorianos de Pernambuco ascendeu à prepositura. $O$ fundador fora uma mistura judiciosa de religiosidade e pragmatismo; o padre Luís Ribeiro carecia de gosto pelos encargos administrativos. Em Portugal, apenas concluídos seus estudos de teologia e filosofia nas célebres aulas de São Domingos de Lisboa, iluminadas, um século antes, pela santidade e pelo saber de frei Bartolomeu dos Mártires, fizera-se ermitáo nas soledades agrestes da serra da Arrábida, de onde o resgatara o proselitismo do padre Quental para enviá-lo ao Brasil. Dez anos instruíra os índios do São Francisco nos mistérios da fé, ocupando-se depois da missáo de Ipojuca, próxima do Recife. Um texto setecentista no-lo descreve táo casto que "nunca falou com mulher que não fosse ou no confessionário ou por respeito à sua salvaçáo, e entáo era com tal modéstia e recato que nunca se soube pusesse os olhos em rosto de diverso sexo"; táo abstêmio que vivia num "perpétuo jejum", sustentando-se de mingau de farinha e de abóboras; táo desprezador de superfluidades que dormia num jirau de varas toscas e nodosas, e que "as suas riquezas se reduziam a instrumentos de penitência e uns poucos cabaços, cuias e surróes que lhe serviam de móveis e adorno das choupanas que habitava Abstinha-se de escrever cartas e detestava recebê-las para não perder tempo com o transitório, sendo ademais (qualidade muito pouco luso-brasileira) "acérrimo inimigo do vício da murmuração". De romaria e festa de igreja, fugia como o diabo da cruz. A esta existência de asceta, ver-se-ia arrancado pela decisáo dos companheiros de roupeta que o elegeram prepósito quando o estado da Congregação pedia chefe dotado de propensóes bem diversas.

Não esmorecera a disposiçáo dos partidários dos estatutos de Lisboa, que constituíam agora a maioria. A pouco tempo da ascensáo do 
padre Ribeiro, a direção da casa resolveu despachar os padres André Luís e Servan Louzel a pleiteá-los do padre Quental. Para tanto, a procuraçáo invocava os claros abertos no recolhimento pela febre amarela, ademais da expulsão de alguns religiosos por "causas que para isso houve" mas que náo explica, e do voto do falecido fundador e deles mesmos, signatários, persuadidos da "larga experiênciá que temos, de que os estatutos de Nosso Santo Patriarca São Felipe' Néri se não podem guardar nestes nossos territórios, como se guardam na Cúria romana". Os emissários deveriam trazer de Lisboa "algum padre ou padres" para guiá-los na observância das constituiçōes quentalianas; e também certo número de oratorianos reinóis que reforçassem os quadros da Madre de Deus. Quando da futura querela os néris do Recife sustentaráo ter havido unanimidade nesta decisão de 1686 , a procuração declarando-se assinada por todos os irmãos. Contudo, aquela referência à expulsão de alguns faz-no crer que esta atingira os partidários do sistema italiano e que o assentimento geral só pôde ser alcançado após o prévio expurgo deles. Além do que, faltavam as firmas de dois recoletos em missão no Ararobá (São Francisco), os quais estarão entre os dissidentes de Santo Amaro, cujo cabeça, o padre João do Rosário, dará, quando consumar-se a ruptura (1688), versáo diferente dos acontecimentos de dois anos antes. A iniciativa da uniáo com Portugal partira de "alguns dos padres, (...) por causa da falta de sujeitos com que ficara aquela Congregaçáo para continuar os exercícios do Oratório no seu hospício do Recife", entenda-se nada tinha a ver com os interesses do recolhimento de Santo Amaro. Era assunto, aliás, a pedir não só ponderaçáo mas também o assentimento geral, condiçáo que não se respeitara, pois estando a frota de partida, não haviam sido consultados os padres que se achavam pelas aldeias, só ouvidos depois, quando sua opiniáo tornara-se inócua. O exame da procuração confirma este relato; e a cisão no Oratório de Pernambuco ocorrerá precisamente ao longo de uma linha de clivagem que separará os padres da Madre de Deus e os padres das aldeias, sediados em Santo Amaro.

Consoante o cronista dos néris fora tal o êxito da missáo que, tendo os procuradores chegado a Lisboa em dezembro de 1686, já estavam de regresso em março seguinte. As coisas não se passaram bem assim. Os padres que aportaram ao Reino em fins de setembro ou começos de outubro, não encontraram no padre Quental a acolhida pressurosa que não se podia, aliás, esperar dele. Sua correspondência com o Oratório de Braga explica suficientemente o porquê das suas reticências. A seu ver, a uniáo do instituto de Pernambuco só poderia ser examinada após definidas as relaçóes institucionais entre a casa de Lisboa e as recoletas que se haviam criado em Freixo de-Espada-à-Cinta, no Porto e 
em Braga, assunto espinhoso, a demandar toda a sutileza clerical e cortesã de que ele era capaz. Tais recolhimentos governavam-se pelos estatutos de Lisboa mas, como ainda existissem autonomamente, reputava-se necessário federá-los mediante um apêndice ou anexo que limitasse a independência de cada um em benefício de uma direçáo comum, chefiado por um prepósito geral. Tratava-se de uma novidade constitucional relativamente ao modelo italiano e inspirada, ou, como já se pretendeu, no Oratório francês, fundado por Bérulle, ou, como querem outros, no autoritarismo do padre Quental. Destarte, os procuradores da Madre de Deus haviam aparecido num momento delicado da história da Congregação. Das cartas de Quental, depreende-se a resistência passiva que no Porto o padre Manuel Rodrigues Leitáo oferecia a seu projeto de estrutura centralizada. Isto explica que os dois religiosos pernambucanos se tenham dado ao trabalho de deslocar-se até aquela cidade, com vistas a obter o consentimento dos do Norte. Só entáo (7 dez. 1686), pôde Quental anunciar haver-se concluído "o negócio de Pernambuco e uniáo daquela casa", acordo puramente bilateral e que não prejulgava a questáo do apêndice, que ainda se arrastará por muito tempo. Em março seguinte, assinaram-se os termos do convênio: a aceitação pelos emissários inclúa não apenas os estatutos mas também o anexo, o qual ainda dependia da confirmaçáo pontifícia e era de todo ignorado dos néris recifenses. Esta flagrante extrapolação dos poderes que lhes haviam sido conferidos estará também na raiz das dificuldades que irão surgir, tendo constituído seguramente uma exigência de Quental, o preço a pagar pela almejada conjunção.

Os padres André Luís e Louzel embarcaram de retorno ao Recife em fins de março. Com cles, viajava o padre Joáo Lobo, incumbido de superintender a aplicaçáo dos novos estatutos. Confessor, pregador e lente de teologia moral, viera ocupando a função de corretor, ou censor, da casa de Lisboa, tarefa insuficiente para satisfazer a indisfarçável vontade de poder de que já dera mostras e que o tornara uma personalidade controvertida. Quando da instalaçáo do Oratório do Porto, ele e o padre Manuel Rodrigues viram-se repelidos pela Câmara local por desejarem se apossar de um orfelinato, expulsando as crianças. Os padres não se haviam dado por vencidos na sua busca de acomodaçóes adequadas e, manipulando a fácil sensibilidade religiosa da populaçáo com uma imagem de São Felipe Néri, proclamaram havê-la casualmente encontrado no interior de uma capela. Que prova mais eloquiente de que a Providência Divina lhes destinava o templo? Desta feita, a Câmara portuense cedeu, doando-lhe o terreno para construção do recolhimento. Ao próprio Quental, aliás, impacientava a maneira forte do padre Lobo. Apenas designado para Pernambuco, começou a recrutar irmáos já desta- 
cados para Braga e para o Porto, o que irritou o fundador, que náo estava disposto a enviar para o Brasil a fina flor dos seus neófitos. A única exceção que se dizia pronto a abrir dizia respeito a certo rapaz que, a despeito de sólidas proteçôes, não poderia ingressar numa das casas do Reino por ser filho do cocheiro de um fidalgo; em Pernambuco, suas origens eram ignoradas, não redundando assim em deslustre do Oratório. Este foi, com efeito, o único congregado que o padre Lobo conseguiu aliciar, mas, em compensação, arrebanhou nada menos de dezoito noviços a quem se devia lançar a roupeta no Recife e que só puderam viajar mercê de uma generosa ajuda de custo concedida por El Rei.

Meados de maio, a Madre de Deus aceitava solenemente o ato de união, firmado por todos os padres, salvo, outra vez, os que se encontravam no sertáo. Passando-se à aplicação dos estatutos, elegeu-se a junta ordinária que administrava o dia-a-dia da comunidade. $\mathbf{O}$ padre $\mathbf{R i}$ beiro foi confirmado como prepósito e os padres Joăo do Rosário, Joáo Álvares da Encarnação e Manuel Néri, como deputados. Ao padre João Lobo, coube obviamente a prefeitura, de onde supervisionaria a aplicação das novas regras. Escolhido procurador, o padre André Luís pediu dispensa, desistência acatada, registra enigmaticamente a ata, devido não só à enfermidade de que padecia mas a "outras mais coisas muito relevantes que sobrevieram". Joáo Lobo iniciou a reforma, mandando colocar rótulas nas janelas e limitando o acesso à casa, de modo a desencorajar os contactos poluidores com o mundo exterior. Entrou também a examinar os livros de contabilidade, averiguação que, segundo a versão dos seus partidários teria constituído o motivo real da dissidência, pois - Oratório de Pernambuco encontrava-se pesadamente endividado, malgrado as inúmeras doaçóes mascatais, mormente no tempo da epidemia. Maio de 1687, a poucos dias do ato de união, já é visível o desgaste nas relaçóes entre os irmáos e os recém-chegados, induzido pelos efeitos da aceitação do apêndice e do que muitos consideravam uma invasão de reinóis. A atmosfera tornou-se táo pesada que as mais influentes personalidades da casa preferiram ausentar-se, o padre Luís Ribeiro para Santo Amaro, o padre Joáo do Rosário para o engenho da Congregação e o padre João Álvares, para a aldeia de Aratangi. O prepósito, aliás, como que lavou as mãos, delegando ao padre Lobo o essencial dos seus poderes para deixar o campo livre à reforma, de certo por não lhe agradarem os métodos do prefeito, que destarte passou a acumular as mais importantes funçóes, como gestor, ao mesmo tempo do espiritual e do quotidiano.

A cisão declarou-se abertamente quando alguns dos religiosos da Madre de Deus recolheram-se também a Santo Amaro, onde não tendo 
conseguido converter o padre Ribeiro à dissidência, trataram de depôlo. A esta altura, dezembro de 1687 , haviam regressado do sertáo os padres das missóes, os quais, abandonando-as vieram juntar-se aos companheiros e, "amotinados (...), chegou o seu atrevimento a tanto que levantaram por prepósito ao dito sacerdote João do Rosárion, que naturalmente contará outra estória. Face à divergência, o padre Ribeiro, por consenso de todos os religiosos, separara as duas casas, procedendo-se à eleição da junta de Santo Amaro e permanecendo o prepósito da Madre de Deus no seu cargo, onde viria a falecer pouco tempo depois, sendo substituído pelo padre João Lobo. No tocante às aldeias, a própria Junta das Missões (órgáo colegiado que as supervisionava, sob a presidência do governador da capitania e com a participaçáo de autoridades civis e religiosas) as havia rateado entre as duas facçóes oratorianas, embora a do Recife ficasse ilegalmente percebendo a totalidade da côngrua concedida por El Rei para a evangelizaçăo do gentio, a qual o padre Lobo empregava no acrescentamento da Madre de Deus. A versão do padre Rosário náo é muito convincente. Ao que saiba, a casa recifense não cogitou a separação, tanto assim que, eleito, o padre Lobo moveu céus e terras para esmagar a dissidência. Devidamente trabalhado pelos néris de Lisboa, o núncio ordenou que os néris pernambucanos fossem submetidos a três meses de noviciado, sob pena de expulsáo ao passo que a recoleta de Santo Amaro era transformada num hospital para os religiosos enfermos, e a Madre de Deus na "principal e verdadeira casa da Congregação". Encarregado da execução do breve, o bispo D. Matias de Figueiredo e Melo ainda tentou congraçá-los, dando por fim aos irredentos o prazo de vinte e quatro horas para que obedecessem, sob a ameaça de excomunhảo maior. Os padres de Santo Amaro opuseram embargos mas $\mathrm{D}$. Matias, famosos pelo seu rigor, não era homem de meias medidas. A dois dos sacerdotes que the foram falar, mandou recolher ao aljube, sem sequer ouvi-los da sua justiça; e, decorrido o prazo, declarou os recalcitrantes por públicos excomungados. À ira episcopal não teriam sido estranhas "algumas exorbitâncias por palavras e escrito" praticadas contra o prelado pelo advogado dos dissidentes, o Dr. David de Albuquerque Saraiva, rascunhando nos autos "cotas escandalosas".

É compreensível que a rejeiçāo aos estatutos de Lisboa partisse dos missionários que haviam optado, por vocaçáo ou até por interesse material como pretendiam seus inimigos, pelo trabalho nas aldeias; e que tendo ingressado na fase heróica do instituto, não haviam sequer sido submetidos a certas exigências da formação eclesiástica, como o noviciado. A disciplina da casa de Lisboa, formulada com vistas a uma existência comunitária em meio urbano, relegara a evangelizaçáo ao papel 
de atividade subsidiária, tanto assim que a regra 16 , única que the dedicou o minucioso texto, não previa sua obrigatoriedade. Suas diretrizes deviam aparecer como uma camisa-de-força a indivíduos habituados a um gênero de vida de fronteira, bastante livre ao menos quando comparada à rotina monótona do recolhimento. Embora náo fossem aplicáveis às aldeias, onde os padres assistiam isolados, vigiriam em Santo Amaro, onde estagiavam periodicamente. Esta diferença entre néris das missóes e néris da Madre de Deus ajuda a entender melhor a disputa do que qualquer outra, inclusive aquela que, na sociedade civil, dominava as mentalidades, cindindo-a em filhos da terra e filbos do Reino. No clero, a naturalidade dos seus membros não se definia, como a dos leigos, mediante o local de nascimento mas em funçáo da província em que haviam professado ou da diocese em que se haviam ordenado, assimilando-se a entrada em religião a um segundo e superior nascimento. Contudo, os oratorianos, fossem de Santo Amaro ou da Madre de Deus, podiam todos considerarem-se igualmente filhos da Congregação de Pernambuco, inclusive os dezoito noviços reinóis trazidos pelo padre João Lobo para vestirem entre nós a roupeta, embora, neste caso, o argumento náo soasse muito persuasivo. Destarte, se a dissidência compôs-se de sacerdotes ou nascidos na terra (como o padre Gaspar da Silva) ou nela chegados em idade tenra (como o padre Joáo do Rosário), o mesmo podia-se dizer dos seus irmãos do Recife - o que não impedirá, porém, a divergência oratoriana de ser cooptada pela dissensão maior que se fazia sentir na capitania entre mazombos e reinóis.

A questão dos estatutos era "todo o Aquiles em que se debate o ponto", como reconhecerá o representante do bispo de Olinda em Lisboa. A rejeiçáo dos dissidentes prendia-se a náo desejarem "estar sujeitos e dependentes do governo da dita Congregaçáo", isto é, do Oratório lusitano, ao que retrucavam os padres da Madre de Deus que a uniformidade da disciplina religiosa não acarretava sujeição, "somente uma uniáo política entre si". Como em Pernambuco, "pela qualidade do clima ou pelo que for, não há muitos sujeitos que se queiram sujeitar à vida de congregados", tornava-se imprescindível ir buscar ao Reino as vocaçóes sacerdotais que rareavam entre nós, o que não seria factível sem as constituiçóes lisboetas. Precisamente numa tal dependência enxergavam os religiosos de Santo Amaro o inconveniente maior de uma associação que os reduziria permanentemente a uma posição minoritária. $\mathrm{Na}$ "ojeriza ao apêndice", o historiador dos néris, Ébion de Lima, detectou "um laivo de nativismo se despertando no mundo eclesiástico brasileiro contra as imposiçóes da metrópolen. A resistência de Santo Amaro feria uma nota que ressoava fundo no meio clerical da capitania, sobretudo nas ordens religiosas trabalhadas desde meados do século 
XVII pelas rivalidades entre professos do Reino e professos do Brasil, mas também na esfera secular, fraturada pela inimizade entre os reinóis e os naturais. Nesta ótica, a verdadeira anexação do Oratório de Pernambuco pelo de Lisboa percorria o caminho oposto à autonomia vis-a-vis das Congregaçóes do Reino, opondo-se ao que chamaríamos hoje o sentido da história, autonomia já reálizada pelos franciscanos ou desejada pelas facçóes mazombas das outras ordens. Náo podia ser outra a interpretaçáo dada ao interepisódio de 1686 , quando o padre Joáo Lobo, forte do pelotáo que trouxera de Portugal para professar no Recife, assumira todo o poder na instituiçáo, dando foros de veracidade à queixa dos dissidentes de que "os padres da Congregaçáo de Lisboa os foram lançar fora de sua casa, fazendo-se senhores do que era seu". Que a controvérsia já se inserira então no confronto entre a loja e o engenho, indica-o uma certidáo passada pela Câmara de Olinda (1688), que tomava a defesa dos separatistas, os quais, havendo fundado o recolhimento de Água Fria, graças ao "dispêndio de suas próprias fazendas e trabalho seu, ajudados de alguns benfeitores", no propósito de levarem uma vida eremítica, assistindo religiosamente à populaçáo pobre dos ermos de Beberibe e convertendo o gentio no sertão, se haviam visto repentinamente perseguidos pelo padre Joáo Lobo, que os queria expulsar da casa de Santo Amaro, valendo-se para tanto do favorecimento de "alguns homens do Recife", a quem o cabedal dava alento.

Acossados pelo bispo, os dissidentes preferiram ingressar em outras ordens a aceitar a uniáo com o Oratório de Portugal. Levantaram-se então as censuras canônicas e lavrou-se o respectivo termo de expulsão. Mas a própria Madre de Deus não estava imune à agitação, menos por solidariedade aos irmãos do que por inconformismo com o estilo ditatorial do prepósito. Escrevendo para Braga, Bartolomeu do Quental resumia as péssimas notícias que recebera de Pernambuco, "não só dos padres que se não quiseram sujeitar às ordens que foram do núncion, vale dizer, os religiosos de Santo Amaro, "mas ainda dos que se sujeitaram, por se náo acomodarem nem poderem sofrer o modo e aspereza do padre João Lobo", isto é, os néris do Recife, que requereram à Lisboa a substituiçáo do prepotente prelado. Quental não contava no momento com companheiro adequado a táo delicada empreitada mas como the houvessem falado no padre Manuel de Vasconcelos, pediu ao colega bracarense que o sondasse a respeito. Vasconcelos não terá demonstrado interesse e provavelmente encarou o convite como uma manobra para afastá-lo do recolhimento, cuja direçáo reclamava até mesmo contra seu estilo de pregar devido ao seu vezo de pontuar com suspiros o final dos sermóes. Quental não entrevia nisto inconveniente maior, parecendolhe preferível deixá-lo "com a sua teima do que inquietarem-se" os ir- 
mãos da recoleta, embora semelhante recurso, tomado de empréstimo : arte dramática e muito usado na parenética das ordens mendicantes resultasse incompatível com a sobriedade e a singeleza cultivadas pelo filhos de São Felipe Néri. Nesta conjuntura, o Oratório de Lisboa re solveu autorizar o retorno do padre Lobo a Portugal e desfazer a uniár com a Madre de Deus, malgrado as reservas do padre Quental, inclinads a esperar que a poeira baixasse. Com o falecimento do prepósito reci fense (1690) dissolveu-se o núcleo de reformadores da casa do Recife uns entrando para o Carmo reformado, outros regressando a Portugal Meados de 1691, as novas de Pernambuco desapontavam Quental "Segundo o bispo me diz, creio que já os expulsos estaráo admitidos, ‘ os que foram com o padre João Lobo, que Deus tem, fora dela", Madr، de Deus. E noutra missiva: "O padre Rosário fica já dentro na Congre gação e já agora estâo os mais expulsos; estão guardando os seus pri. meiros estatutos, e tudo como dantes da ida do padre Joáo Lobo, se nã́c for pior; e temos acabado com aquela Congregação". Olhada de Lisboa a reviravolta parecia definitiva, mas não o era.

Desaparecido o padre Lobo, o grupo que solicitara os estatutos dt Lisboa mas repelira o takeoper pelos reinóis, recuperou a iniciativa, entrando num entendimento com os companheiros de Santo Amaro. Na Bahia, negociou-se um acordo pondo termo à cisão. O padre Rosário $\epsilon$ quatro outros dissidentes eram readmitidos, tornando-se ele mesmc prepósito e dois dos seus sectários, deputados. A composição previa também que, na dependência de uma solução do problema dos estatutos, observar-se-iam na igreja os de Lisboa e no recolhimento, os de Roma; na realidade, parece que os primeiros continuaram a vigir em ambos os recintos. A transação foi de pouca dura. Havendo repudiado o padre Lobo, a Madre de Deus não iria agora acatar docilmente o padre Rosário. Decorridos seis meses, o prepósito e o padre Domingos Gonçalves foram depostos e recluídos nas suas celas, sob a acusação de haverem-se envolvido com a arrematação de dízimos, contrariando as regras oratorianas. Feita nova eleição, saiu prepósito o padre Agostinho Nunes. O padre Rosário conseguiu fugir para a Bahia e o bispo D. Matias procurou sem êxito aliciar seus correligionários. Em Salvador, os néris de Santo Amaro engajaram a batalha judiciária, apelando diretamente para o Papa. Com alguma simpatia deviam contar no Vaticano, que expediu um breve encarregando o arcebispo da Bahia de tomar conhecimento da causa. Delegada a competência ao vigário geral, este deu-lhes sentença favorável. A Madre de Deus recorreu à instância superior, no caso o núncio em Lisboa, que confirmou a decisão; e depois à Santa Sé, que desta vez ordenou ao legado em Portugal que designasse um juiz para rever o processo. A escolha recaiu em D. Manuel Álvares 
da Costa, futuro bispo de Olinda e futuro governador interino de Pernambuco, mas que então era desembargador da Relaçáo eclesiástica. $D$. Manuel confirmou o primeiro julgamento, datando daí uma longa rixa com os oratorianos do Recife, que ainda năo lhe haviam perdoado quando, mais de dez anos depois, ele assumiu seu ofício pastoral em Olinda.

A sentença mandava repor os expulsos no estado em que se achavam quando da deposiçáo do padre Rosário. O vigário geral da Bahia interpretara-a, contudo, de maneira indevidamente lata, ordenando também que se restaurassem os estatutos de Vallicella. D. Manuel delegara como juízes executores o vigário geral de Olinda e o deáo do bispado, mas como ambos se negassem a aceitar o encargo, comissionou-se o vigário geral da Bahia junto a quem os padres de Santo Amaro gozavam de uma influência inconteste, resultante de consideraçóes de política eclesiástica que permanecem obscuras para o historiador. Não podendo ou não querendo deslocar-se a Pernambuco, o Dr. Joáo Calmão subdelegou o mandado em qualquer das pessoas seguintes que se dispusesse a aplicá-lo: o guardiāo franciscano do Recife; certo frei Benedito de Sáo Bernardo, da ordem de São Bento; o prior dos carmelitas descalços de Santa Teresa, de Olinda; e o visitador dos beneditinos. A lista era de encomenda, pois incluía, ao menos, três exaltados parciais dos dissidentes. A comissão chegou ao Recife, trazida da Bahia por um néri de Santo Amaro, sobrinho do padre Sacramento. A despeito de apoiar a causa dos expulsos, o primeiro nomeado recusou o encargo, de modo que ele foi parar nas máos de frei Benedito, que o aceitou alacremente, tanto assim que, encontrando-se em Sirinhaém, a dezesseis léguas da praça, regressou.imediatamente a Olinda, começando a atuar com uma desusada energia, apesar de achar-se inabilitado, não sendo religioso em dignidade constituída mas apenas um monge graduado em teologia (este será, aliás, um dos pontos mais controvertidos da disputa, sustentando seus partidários que, como juiz executor, cumpria-lhe apenas implementar uma decisáo canônica de autoridade superior, para o que bastava sua condiçáo sacerdotal). Como escrivăo, frei Benedito nomeou seu companheiro de claustro, frei Manuel da Assunção, face à impossibilidade de contar com os serviços do notário eclesiástico, que teria sido coagido pelo bispo a escusar-se.

É que o êxito da missão, já de si duvidoso, tornara-se remoto em consequiência da simpatia do quarto bispo de Olinda, D. Francisco de Lima, pela causa da Madre de Deus. Quando frei Benedito o visitou para comunicar-lhe a comissão, o prelado tentou dissuadi-lo de executá-la sugerindo que esperasse pelas decisóes frescas a serem trazidas pela frota, sugestáo sintomática de que os oratorianos do Recife davam como 
favas contadas uma solução favorável, como a que virá precisamente a chegar dentro de alguns meses. Perspectiva que era uma razão adicional de pressa para os dissidentes, desejosos de criar o fait accompli, que os colocaria numa posiçáo privilegiada em qualquer negociação futura. Aliás, no decurso da conversa com o bispo, o frade não exibiu o documento que trazia consigo e que tampouco lhe foi solicitado pelo interlocutor. Que ambos se tenham abstido de um e outro gesto é bem indicativo das segundas intençóes com que agiam, pois uma vez exposta a comissáo o prelado teria, de acordo com os canonistas da mitra, de apor-lhe o cumpra-se, o que náo estava disposto a fazer; e o frade, de rejeitá-lo para não reconhecer a preeminência de $\mathrm{D}$. Francisco.

Dia 30 de setembro de 1699 , o frade e o escrivăo compareceram à Madre de Deus para notificar os padres, intimando-os a cumprir integralmente a sentença no prazo de três dias. Os néris deram a citaçáo por nula, alegando erro de forma, uma vez que o correspondente monitório não transcrevia o texto da comissão. Em seguida, foram muito lusitanamente queixar-se ao bispo, ao passo que, com a conivência do governador Fernando Martins Mascarenhas, metiam soldados no recolhimento para obstar a eventualidade de um golpe de mão. $O$ bispo reagiu, considerando arranhada sua autoridade e, não tendo dado o cumpra-se, violada sua jurisdição ordinária, passando a exigir que frei Benedito lhe apresentasse a comissáo, o que náo havia feito antes, como também o título de estar constituído em dignidade eclesiástica. $O$ frade, após objetar que se achava isento de tal obrigaçáo, mudou de tática fornecendo cópia da delegaçáo. D. Francisco despachou o traslado para exame do vigário geral, ordenando ao beneditino que sustasse quaisquer medidas sob pena de excomunhão. O comissário retaliou, declarando os néris públicos excomungados por contumácia. Nesta verdadeira loja de louças que era o direito canônico, frei Benedito atuava com a sutileza de um touro, incorrendo, segundo os entendidos, em nada menos de cinco nulidades de caráter processual, que seria monótono debulhar aqui. Deflagrou-se entáo uma daquelas guerras clericais cujo drama nossas sociedades secularizadas já náo conseguem apreciar e nem sequer compreender. D. Francisco excomungou o frade por interferir com a jurisdiçáo episcopal e anulou o interdito contra os néris. $O$ juiz executor respondeu, excomungando o bispo e o vigário geral e agravando as censuras contra a Madre de Deus. Apenas o pessoal da mitra arrancava as proclamaçóes do frade dos lugares públicos em que eram, como de praxe, afixados, seus partidários corriam a repô-los; e reciprocamente. $O$ espetáculo, já desmoralizante para a autoridade eclesiástica, ultrapassou em seguida as fronteiras de uma disputa clerical para envolver os agentes da Coroa. 
A pedido de D. Francisco de Lima, o governador Fernando Martins Mascarenhas convocou uma junta de altos funcionários e letrados para se pronunciar sobre a controvérsia. O resultado do debate foi unanimente favorável ao bispo, concluindo que houvera violação da sua jurisdição. D. Francisco propôs nova conferência, desta vez entre seus partidários e os do frade, engajando-se de antemáo em aceitar o que nela se resolvesse. As razóes da sua flexibilidade deu-as em parte em carta a El Rei: a ordem pública estava a ponto de quebrantar-se de modo que cumpria "evitar os escândalos e as perturbaçốes, pois de sorte se iam aumentando que com grande fundamento se podia temer seguirem-se prejudiciais consequiências, as quais eu devia atalhar, ainda que fosse cortando pelo meu respeito [isto é, em detrimento da sua autoridade] e sujeitando-se ao parecer dos mais votos". Frei Benedito concordou com a idéia, combinando-se, para o dia seguinte, no palácio das Torres, a reunião entre os letrados e teólogos de Olinda e do Recife, distinçáo que, feita nos textos relativos à contenda, bem indica a inserçáo do dissídio religioso na polarizaçáo predominante na sociedade pernambucana. Contudo, no dia seguinte o frade recuou, mandando dizer que "os teólogos e juristas da cidade a não aprovavam e o aconselhavam a que não fizesse". Os dissidentes davam como razáo a maioria de votos de que disporiam o bispo e o governador; a parcialidade com que atuavam em benefício da Madre de Deus; e a opiniāo, expressa por um douto, o provincial da Companhia a de Jesus, segundo a qual, em caso de conflito entre o delegado do Papa e o ordinário, náo havia lugar para recorrer a árbitros, a superioridade pertencendo ao primeiro. Face ao impasse e à comoção pública, só restava a D. Francisco pedir a Fernando Martins Mascarenhas a intervenção do braço secular, isto é, o uso da força contra os religiosos recalcitrantes. O bando governamental ( 9 out. 1699) que o atendeu, previa também penas de degredo e outras contra os laicos que agissem, por palavras ou atos, contra o prelado.

O documento comprova, aliás, que a briga dos néris deixara há muito de ser uma mera querela entre irmãos de roupeta para implicar as principais camadas sociais, a nobreza e a mascataria, acicatando as emoçóes populares. Em uma referência aos pró-homens, aludia o governador à atuaçáo de "alguns sujeitos", de "grande estado", que há muito fomentavam as perturbaçóes da capitania e que agora sustentavam na sombra os dissidentes de Santo Amaro. Náo me parece com razão Ebion de Lima ao assinalar que "a camada superior da populaçáo afinava com o bispo", enquanto "o povo", instigado pelos frades, bandeara-se para frei Benedito. Na realidade, a cisão manifestou-se no estrato superior, segundo as linhas já nossas conhecidas, da clivagem entre a açucarocracia e os mercadores, que há muito cultivavam as relações com Santo Amaro 
e com a Madre de Deus respectivamente. A novidade consistiu antes na dissensão entre seculares e regulares, aqueles a favor do bispo, estes, em grande parte do lado do frade. $O$ grande receio dos representantes da Coroa dizia respeito aos riscos de uma sediçáo, estimulada por elementos da nobreza, com a ajuda dos dissidentes e de parte, talvez majoritária, do clero regular que os apoiava, menos por solidariedade sincera do que por ressentimento contra a Madre de Deus. As excomunhóes trocadas pelo bispo e pelo frade paralisaram a vida religiosa da comunidade, agredindo um quotidiano dominado pelo sagrado. Boa parcela dos fiéis observou as censuras de frei Benedito contra e em dano da autoridade de D. Francisco. O cabido de Olinda e o clero secular, diretamente subordinados ao prelado, prestavam-lhe obediência, mas os regulares achavam-se divididos. "Resultaram tais alteraçóes", narrará o bispo, "que temi originar-se delas uma grande ruína", só prevenida graças à intervençáo do governador, pois sem ela "se arriscaria aquela cidade com grandes sediçóes e motins", nas palavras de um oratoriano. A paz só pôde ser mantida mediante a solidariedade inquebrantável que prevaleceu entre a tróica composta do governador, do bispo e do ouvidor Dr. Manuel da Costa Ribeiro - , uniâo que precisamente faltará dez anos depois quando o prelado e o magistrado da época se coligarem contra o governador Castro e Caldas.

Foram os capuchos, ou franciscanos reformados, e os terésios, ou carmelitas descalços, os principais promotores da agitação. Se estes gozavam de influência reduzida, aqueles pelo contrário, pertenciam à ordem hegemônica na capitania, quer pelo número de seus conventos $\mathrm{e}$ pela sua implantação rural, de que as demais religióes careciam, quer pela sua popularidade em todas as camadas sociais. Os guardióes dos conventos franciscanos do Recife e Olinda mostravam-se os mais exaltados de todos, negando-se mesmo, como o prior de Santa Teresa, a comparecerem a uma reunião da Junta das Missóes, marcada para discutir a liberdade dos índios do Jaguaribe (Ceará), com a explicação de estarem canonicamente proibidos de falarem com o bispo e com os oratorianos. Desde o recebimento da comissão, os capuchos e os terésios haviam cessado de freqüentar o paço episcopal, e uma vez deflagrada a crise, passaram, do alto do púlpito, a desancar $\mathrm{D}$. Francisco, procurando este, segundo dizia, "por todos os caminhos que a maldade costuma descobrir, descompor-me e desacreditar-me com os povos", inclusive exortando os fiéis, a bem da salvaçáo das suas almas, a não freqüentarem as igrejas da diocese, interditas em decorrência da excomunhão do prelado por frei Benedito, único representante legítimo do Papa no bispado, conforme proclamavam. D. Francisco tinha reproches a favor a uns e a outros. Para ele, os descalços, também chamados marianos, não 
tinham qualquer utilidade em Pernambuco, aonde chegavam "despidos do espírito de Santa Teresa, para procurarem o temporal e para o inquietarem", apreciação que traduzia talvez certa má vontade de seita, pois o bispo era carmelita calçado. Quanto ao guardiáo do convento franciscano do Recife, frei Cosmo do Espírito Santo, acusava-o de acolher "os clérigos criminosos e suspensos nas ordens, consentindo-lhes que usem delas como se não estivessem excomungados", ademais de praticar "outras coisas mais que me causam grande escândalo".

Em resumo, seus inimigos "fizeram tão crescida a tempestade que receei ver-me dela submergido". D. Francisco, que deixou fama de orador sacro, transmitiu a El Rei uma descrição gráfica destes dias ansiosos: "Com esta resoluçáo de frei Benedito [rejeitando a conferência], se foram aumentando os tumultos e as perturbaçóes em quase todo o bispado, introduzindo-se nele um pernicioso e abominável cisma, ocasionado por aqueles mesmos que, em razão do seu estado [clerical], devem solicitar toda a paz e concórdia, ajudando o bispo no cuidado que deve ter das suas ovelhas, pois este é o fim para que Vossa Majestade lhes dá licença e consente façam fundaçóes nestas conquistas e o para que o bispo os ordena e lhes dá licença para confessarem e pregarem a palavra de Deus. E não para andarem pelas praças, casas particulares e mesmo nos confessionários, persuadindo a todos que o bispo estava excomungado e o ficavam todos os que lhes obedeciam, afirmando o mesmo de todos os congregados. E chegou a tanto a ignorância e atrevimento do guardião dos capuchos do Recife, (...) que se pôs à porta da sua igreja e a todos os que sabia ou confessavam tinham ido à Congregaçáo, os não deixava entrar sem que prometessem de não tornar a ela, e com esta condiçáo os absolvia com varas publicamente, para o que dizia ter licença de frei Benedito, o qual em Pernambuco representava o Papa. E desta sorte, sendo frei Benedito o Papa em Pernambuco, cada um dos frades assim capuchos como descalços se considerava bispo."

Outros conventos também comportaram-se de maneira irredenta, a acreditar-se no governador, que acusou seus prelados de favorecer os dissidentes. Uma representação dos padres de Santo Amaro jactava-se de que: "... nenhuma pessoa douta ou científica de todo aquele bispado deu crédito nem guardou os interditos do dito Ilustríssimo Bispo, tanto assim que todas as religióes, como foi a de Sáo Francisco, a dos carmelitas descalços, a de São Bento, capuchinhos franceses, carmelitas reformados e a da Companhia de Jesus, nas quais assistem os sábios e os prudentes, todas estas religióes e conventos, assim da cidade como do Recife, guardaram e observaram os interditos postos pelo dito reverendo bispo executor $(. .$.$) nenhuma religiăo das acima referidas deu crédito$ 
às anulatórias que o dito Reverendíssimo Bispo mandou passar contra os procedimentos do dito reverendo juiz executor e muito menos as censuras e interditos que contra este mandou passar e fixar, por todos reconhecerem o defeito de sua jurisdiçáo nesta matéria e a pouco justificada causa que para isso tinha."

Há, contudo, que matizar a imagem de unanimidade que o texto acima busca impingir. Da coalizão antiepiscopal, o governador isenta os religiosos do Carmo de Olinda e de São Bento, os primeiros, irmãos de ordem de D. Francisco; e os beneditinos, influenciados pelo seu visitador e dom abade, que se demarcaram do colega, o juiz executor. Quanto aos inacianos, os do Recife acabaram cedendo à anulatória do bispo, abrindo as portas da igreja aos fiéis.

De mãos dadas com os capuchos e terésios, atuava o advogado dos dissidentes, um cristáo novo do Reino, David de Albuquerque Saraiva, que Fernando Martins Mascarenhas descrevia como "um letrado não formado, (...) homem sumamente apaixonado e fomentador dos expulsos" e a quem outrora o bispo D. Matias degredara para Angola "por insolente, menos afeto à Igreja e animosamente loquaz". O rábula servia de assessor jurídico de frei Benedito, redigindo os arrazoados e outros documentos necessários à demanda, mas extrapolava perigosamente sua função, assumindo "o ofício de pregador", não nas igrejas, obviamente, mas nos lugares públicos, fazendo da janela da sua casa nos Quatro Cantos, em Olinda, palanque de comícios demagógicos contra o governador, o bispo, o Oratório e seus partidários. Como sua eloqüência se tornasse incendiária, Fernando Martins no ponto agudo da crise, mandou-o prender, mantendo-o incomunicado no calabouço de uma fortaleza do Recife. Solto, David de Albuquerque reincidiu nas arenas subversivas, razão pela qual o governador, ainda temeroso de "algum tumulto na cidade de Olinda", expulsou-o para a Paraíba, medida, aliás, desaconselhada por $\mathrm{D}$. Francisco de Lima e pelos néris do Recife, que a consideravam contraproducente. Fernando Martins teve, porém, o cuidado de afetar imparcialidade, e dando uma no cravo e outra na ferradura, baniu também da capitania o letrado que, acumulaçáo suspeita, exercia simultaneamente as funçōes de procurador da mitra e de advogado da Madre de Deus. Por detrás da atuaçáo de David de Albuquerque, estaria um dos mais turbulentos pró-homens, Francisco Berenguer de Andrada, velho inimigo do bispo D. Matias e cunhado de João Fernandes Vieira. Consoante denúncia do sargento-mor Pedro Lelou, Berenguer, "mau homem e diabólico em fazer manifestos falsos", respondia a nada menos de sessenta e dois processos, "sem pagar nem restituir o alheio, um verdadeiro perturbador da república, semeando nela mil cizânias". 
Ao governador, não competia interferir no mérito de uma disputa exclusivamente eclesiástica; apenas, como primeira autoridade laica, acautelar a ordem pública. A contenda retornará agora ao arcebispado da Bahia, de que Olinda era sufragâneo e a que recorreu o bispo. Para lá, partiu também frei Benedito, que achara mais prudente retirar-se em vista da ordem de prisão que contra ele baixara D. Francisco. Alegariam os dissidentes haver-se tomado também a mesma medida contra os cabeças do movimento antiepiscopal, incriminados em processos que tramitavam no foro eclesiástico, "de sorte que todos andaram fugidos, sem que houvesse [lugar] sagrado em que se dessem por seguros, nem coito a que tivessem tido acesso, até que a cada um foi forçoso ausentar-se para lugares remotos e alguns deles para fora do bispado". Versão que o prelado desmentia, admitindo apenas a existência do mandado contra frei Benedito, estribado no direito canônico, que reconhecia aos ordinários o direito de pedir o auxílio do braço secular contra os juízes delegados acusados de excessos. Era certo que um dos padres de Santo Amaro se refugiara entre os franciscanos de Olinda, viajando depois para a Bahia; havia-o feito, porém, com base em falsos rumores. Outro, João do Rosário, homiziara-se no convento de Santo Antônio do Recife, e um terceiro, Domingos Gonçalves, no de Santa Teresa, no único propósito de se fazerem de vítimas dele, D. Francisco.

$\mathrm{Na}$ Bahia, os dissidentes perdiam apoio. A Madre de Deus interpusera agravo junto ao tribunal da Relação, que lhe deu ganho de causa, anulando as diligências de frei Benedito, por ultrapassar sua competência, e mandando que se desse novamente à execuçăo a sentença proferida por D. Manuel Álvares da Costa. Era sobretudo na área eclesiástica que o clima tornara-se hostil à causa de Santo Amaro. O arcebispo e o vigário geral revogaram a comissáo e mandaram que se processasse o beneditino em Olinda, onde naturalmente concluiu-se pela sua culpabilidade. Em Salvador procedeu-se agora à sua excomunhão e a hierarquia eclesiástica năo poupou o atrevido que se apresentara em Pernambuco como representante do Papa e como o superior do bispo. Na dominga da Quaresma de 1700, frei Benedito foi expulso da Sé de Salvador para que sua presença não maculasse a pureza da missa que se ia celebrar. No próprio convento de sua ordem, proibiram-no de assistir à cerimônia de sagração do novo bispo de São Tomé. $O$ frade, porém, não se entregava, incentivando os amigos pernambucanos, recusando a absolvição que lhe ofereceram em troca do arrependimento e até dizendo-se preparado a prosseguir a luta em Roma. Mas o Oratório português não cruzara os braços. Incentivado por ele, D. Pedro II, sob o efeito sentimental do falecimento do padre Quental (22 dez. 1698), intercedera junto a Inocêncio XII para que solucionasse a questáo dos estatutos. Ao tempo em 
que o cenário deslocara-se para a Bahia, eis que a frota de 1700 trazia a Pernambuco o decreto da Sagrada Congregaçáo da Propaganda Fide (16 nov. 1699), golpe contundente para os néris de Santo Amaro. Ambas as casas deveriam pautar-se pela disciplina de Lisboa; o padre João do Rosário e companheiros seriam readmitidos e, caso não o desejassem, expulsos, restituindo-se-lhes os bens que houvessem doado à Congregaçăo. "Com a notícia deste decreto", constatava aliviado D. Francisco de Lima, "foi amainando a tempestade e conhecendo todos a verdade". O prelado mandou notificar os dissidentes para que jurassem as constituições lisboetas como condição prévia à sua reintegraçăo nos postos de que haviam sido esbulhados quando da deposiçáo de Rosário, mas eles não se haviam resignado à derrota, replicando terem embargos a opor ao decreto, por considerá-lo fundado em informaçóes falsas e distorcidas. De modo que "os frades, assim capuchos como descalços, vendo que com a notícia do decreto se iam sossegando os tumultos que eles tinham levantado e [que] com a paz viriam todos no conhecimento das suas maranhas, temendo o castigo que por elas merecem, divulgaram que o decreto era subreptício e que não só o havia de r[ev]ogar o Pontífice mas dar uma severa repreensão ao bispo" .

A agitaçáo cessara nas ruas, mas recomeçou nos conventos, onde, segundo o governador, "em nada se emendaram as opinióes e ainda houve religiosos que afoitamente pregavam e ensinavam contra o reverendo bispo". Num homilia da Quaresma, um frade capucho excederase nos recursos retóricos: "o menos que disse do púlpito foi que, assim como por Ana Bolena entrou a heresia em Inglaterra, assim pelo bispo havia entrado um cisma em Pernambuco". Queixavam-se os dissidentes das perseguiçóes que D. Francisco movia aos franciscanos, ordenando aos párocos lhes interditassem o acesso às igrejas diocesanas, onde não podiam dizer missa, nem pregar, confessar ou dar a comunhão, ficando ameaçado de excomunhão maior quem quer que deles recebesse os sacramentos ou acudisse a atos religiosos por eles celebrados. Alegaçáo que o procurador da mitra em Lisboa negará, explicando que do prelado náo partira ordem alguma contra os frades, salvo a suspensão do que o chamara de cismático, suspensão que, aliás, levantara ao inteirar-se de que já o atrevido havia sido castigado pelo guardiáo. Ocorrera apenas que, por um zelo compreensível, alguns vigários haviam recusado acesso a certos conventuais sectários que utilizavam o santo sacrifício da missa para ventilar seus ódios incontidos contra o pastor da igreja pernambucana. A realidade, escrevia $\mathrm{D}$. Francisco, é que seus inimigos haviam tomado o pinháo na unha e estimulavam os dissidentes a persistirem no interminável litígio, ademais de circularem "muitas certidóes contra o meu procedimento, do que dando-se-me notícia e sabendo que o padre 
frei Antonio do Sacramento, frade descalço, as andaria assinando [isto é, obtendo assinaturas] pelos engenhos, the mandei dizer que me compadecia do trabalho em que andava, só, sem companheiro, correndo os engenhos, podendo com menos custo conseguir o seu intento, porque mandando-me as certidóes, se fossem verdadeiras, inda que contra a minha pessoa, lhe dava palavra de as assinar e que só com o meu sinal se fariam mais dignas de crédito do que outros, por muitos que fossem; e que se eram falsas, entendesse que de um trabalho tão indecoroso ao seu estado e tão alheio dos filhos de Santa Teresa e do fim por que Vossa Majestade os consente neste estado de Pernambuco tanto à custa da sua real fazenda, só podia tirar descrédito e menos reputaçáo, porque a verdade é sem comparaçáo alguma mais poderosa que todos os inventos da maldade e da mentira e certamente há-de prevalecer."

Admoestaçóes que náo fizeram o menor efeito, prosseguindo a coleta de certidóes (o correspondente ao que hoje se designa por abaixo assinado) para serem enviadas pela frota, coleta que, aliás, o bispo reconhecia ser abundante e o trazia preocupado. São obscuras as razōes do antagonismo entre os franciscanos e $\mathrm{D}$. Francisco, mas não parece improvável que fossem da mesma natureza das que almejam os terésios, vale dizer, disputas pelo controle das missóes, grande motivo das discórdias entre regulares. Os descalços haviam obtido em Lisboa a promessa de que lhes seria entregue a aldeia de São Caetano mas o prelado relutava em atendê-los, desejando mantê-la a cargo de um padre, protegido seu. Duas povoaçóes haviam sido criadas nos Palmares, à raiz da destruição do quilombo, a primeira, esta de São Caetano, situada nos arredores de Porto Calvo, regiáo açucareira, capaz de sustentar facilmente os religiosos; a outra, localizada no próprio oiteiro da Barriga, sítio remoto e fragoso, era a que o bispo reservava aos terésios. $O$ prior de Santa Teresa, frei Manuel de Santa Inês, explicava a teimosia episcopal náo só pela oposição de $\mathrm{D}$. Francisco à presença de regulares nas aldeias, mas também pela animadversáo que, carmelita cạlçado, teria contra os descalços. Após a partida do governador Caetano de Melo de Castro, o prelado passara a dominar as decisōes da Junta das Missōes, razáo pela qual náo se resolveria favoravelmente o pleito, apesar do apoio dispensado à pretensão pelas demais ordens. Ocorre que o labor missionário era vital aos planos dos terésios em Pernambuco, onde se haviam estabelecido há poucos anos e onde ainda se achavam na dependência da confirmaçáo régia do seu convento de Olinda. Que este era o seu tendão de Aquiles, conclui-se, aliás, da já citada carta do bispo a El Rei, na qual assinala que, não administrando aldeia alguma, eles eram perfeitamente desnecessários na diocese. 
O Conselho Ultramarino examinou o assunto em fins de 1700. Reconhecendo a legalidade das comissóes de D. Manuel Álvares da Costa e do vigário geral da Bahia, concordava em que a atuaçáo de frei Benedito estivera viciada de nulidades e aprovava a atitude de $D$. Francisco. Condenava, porém, a interferência do governador, que cometera o abuso de se pronunciar, no seu bando, sobre o mérito das excomunhōes reciprocamente proferidas, o que não lhe dizia respeito. David de Albuquerque Saraiva via-se autorizado a regressar a Pernambuco contra a promessa de náo mais se imiscuir na disputa. Para resolvê-la de uma vez por todas, opinava o Conselho, El Rei deveria intervir pessoalmente, conciliando os religiosos sem o recurso aos meios judiciais; bastaria convocar à sua real presença os procuradores da Madre de Deus e de Santo Amaro em Lisboa, os quais dispunham de poderes suficientes para negociarem uma transaçăo amigável, pela qual os dissidentes acatariam os estatutos portugueses em troca da sua reintegraçáo, assumindo a casa do Recife os ônus financeiros em que tivessem incorrido no tempo da expulsáo. A sugestáo pecava por otimismo; os rancores haviam-se feito entranháveis, como pudera constatar um observador de fora, o padre Miguel de Carvalho que, procedente da Bahia, fizera escala em Pernambuco em outubro de 1700 . Numa informação a Roque Monteiro Paim, secretário de estado de $\mathrm{D}$. Pedro II, năo poupava ninguém pelas desordens. "Todos os que entraram nelas", afirmava, "atenderam mais aos caprichos particulares do que ao bem comum e, sem repararem no lícito ou ilícito dos meios, tudo o que fizeram e o que dizem se encaminhou e encaminha a [determinar] qual triunfará vencedor sem ficar vencido". Convencido talvez pelo argumento e náo querendo arranhar o prestígio da Coroa, El Rei rejeitou a idéia de compromisso, aventada pelo Conselho, preferindo empenhar-se por uma decisão pessoal e definitiva do Santo Padre, através do embaixador junto ao Vaticano.

Os dissidentes ainda enviaram a Roma o padre Gaspar da Silva, na esperança de conseguir a revogaçáo do decreto da Propaganda Fide. Mas a causa estava definitivamente perdida: Clemente XI satisfez D. Pedro II, colocando um ponto final na controvérsia e pela bula Ad futuram rei memoriam (10 dez. 1701) avocou-a a si, invalidando todas as demandas e todas as sentenças a que havia dado lugar, bem como as censuras eclesiásticas proferidas de uma e outra parte, ademais de confirmar o decreto da Propaganda Fide e de impor perpetuo silencio sobre a matéria. Os padres de Santo Amaro, informa Loreto Couto, "largaram a recoleta e uns professaram em religióes aprovadas e outros, que ficaram no século, fizeram sempre uma vida exemplar e penitente". O travo da sua derrota ainda será perceptível meio século depois, em alguns passos 
dos Desagravos do Brasil. É certo que as exigências da disciplina eclesiástica náo permitiam ao seu autor ir muito longe na crítica, tanto assim que tomava o cuidado de explicar a rejeiçáo dos estatutos de Lisboa com o argumento de que "pessoas ainda que santas são sujeitas a temerários impulsos" . Náo é menos verdade, por outro lado, que, nas entrelinhas, a adoçáo da disciplina portuguesa em 1687 aparece como o resultado de uma iniciativa dos procuradores da Madre de Deus mancomunados com - Oratório metropolitano e também das "diversas contradiçóes que se armaram contra os primeiros congregados por outros, que vieram do Reino, fomentadas pelo padre Joâo Lobon. Em Roma, onde viria a falecer quando da sua malograda missão junto ao Papa, o padre Gaspar da Silva vira "suas diligências superadas de forças contrárias, senão mais naturais, mais poderosas". Contudo, o triunfo definitivo dos néris só terá lugar nove anos passados da bula de 1701, quando o Recife for promovido a vila e quando a repressão da Coroa houver desbaratado seus inimigos seculares, os pró-homens e a Câmara de Olinda, completando no século a obra encetada entre as paredes da Madre de Deus.

\title{
Resumo
}

Neste artigo, o autor chama a atenção do leitor para o papel representado pelas ordens religiosas no Brasil colonial, com relação ao aparecimento dos sentimentos nativistas. Como um estudo de caso das relaçóes de nativismo e religiăo, é examinada a história do cisma que aconteceu em Pernambuco, no final do século XVII, entre os padres do Oratório. O exame da disputa é feito em seus próprios termos, mas também à luz das crescentes tensōes políticas, sociais e econômicas entre os proprietários de engenhos de açúcar e os meios comerciais do Recife. O autor conclui mostrando que ambos os lados do conflito oratoriano eram apoiados tanto pelos nobres de Olinda quanto pelos comerciantes do Recife.

\begin{abstract}
In this article, the author tries to the draw the attention of the reader to the role played by the religious orders in colonial Brazil in connection with the rise of nativist feelings. As a case study in the relations of nativism and religion, he examines the history of the rift that took place in Pernambuco at the end of the 17th Century among the priests of the Oratory. He reviews the dispute in its own terms but also in the light of the increasing political, social and economic
\end{abstract}


tensions between the sugar mill owners and the commercial circles of Recife. He concludes by showing that both sides in the oratorian conflict were supported either by the nobles of Olinda or the traders of Recife.

Evaldo Cabral de Mello é diplomata de carreira. É o consul do Brasil em Marselha, França. Foi cônsul geral em Lisboa (1987) e em 1991 ocupou a função de embaixador em Bridgetown, Barbados. E autor de vários trabalhos historiográficos, entre eles, Olinda Restaurada - Guerra e Afucar no Nordeste 1630-1654 (Sáo Paulo, Edusp-Forense Universitária, 1975) e Uma fraude genealógica no Pernambuco colonial (São Paulo, Companhia das Letras, 1989).

Conferência do Mês do IEA-USP feita pelo autor em 26 de outubro de 1993. 